\title{
Waiving of rights to property in insolvent estates and advantage to creditors in sequestration proceedings in South Africa
}

\author{
Roger Evans \\ BLC LLB LLD \\ Professor of Mercantile Law, UNISA
}

\begin{abstract}
OPSOMMING
Voordeel vir skuldeisers by insolvensieaansoeke en die afstanddoening van die regte van skuldenaars in hierdie aansoeke
\end{abstract}

In vandag se samelewing, en veral in Suid Afrika, wend die meeste mense hulle tot die leen van geld ten einde hul daaglikse bestaan te finansier. Gevolglik was daar nog altyd 'n behoefte aan professionele hulp in gevalle waar die skuldenaar probleme ondervind met die terugbetaling van sy of haar skuld. Sodanige hulp word gewoonlik daargestel deur wetgewing. In Suid Afrika word die Insolvensiewet 24 van 1936 hoofsaaklik gebruik om hulp te verleen aan partye by die kollektiewe skuldinsamelingsprosedure wat die sekwestrasie van die skuldenaar se boedel beoog. Sekwestrasie is onder andere veronderstel om te lei tot die rehabilitasie van die skuldenaar en dus 'n nuwe kans op finansiële herstel. Vir die sekwestrasie van ?n skuldenaar se boedel vereis die Insolvensiewet bewys dat sekwestrasie tot voordeel van skuldeisers sal wees. 'n Probleem wat ontstaan is dat daar in sommige gevalle'n potensiële voordeel vir skuldeisers bewys kan word, maar in ander gevalle nie. Dus word "arm" of minder-bevoorregte individue verhoed daarvan om gebruik te maak van die prosedure en regte wat die Insolvensiewet daarstel, en daarom ook die voordeel van rehabilitasie. Skuldenaars probeer om hierdie probleem van "voordeel vir skuldeisers" te omseil deur afstand te doen van sekere "regte" wat die Insolvensiewet aan hulle toeken. Dit skep die indruk dat hulle boedelwaarde voldoende is om voordeel te bewys. Die Hoë Hof het egter bevind dat sodanige afstanddoening nie moontlik is nie, en gevolglik ontoelaatbaar.

Hierdie probleem lei tot die vraag of minder-bevoorregte skuldenaars in sulke omstandighede ongelyk behandel word, en of sulke behandeling in stryd is met die vereistes van die Suid-Afrikaanse Grondwet, 1996. Die artikel ondersoek dus die kwessie van voordeel vir skuldeisers by insolvensieaansoeke; die afstanddoening van regte van skuldenaars in hierdie aansoeke; en die moontlike ongrondwetlikheid van die beleid van "voordeel aan skuldeisers" in die Suid-Afrikaanse insolvensiewetgewing. Die skrywer kom tot die gevolgtrekking dat die ongelyke behandeling van skuldenaars in die toekoms heel moontlik voor die Grondwetlike Hof kan beland. Maar alvorens dit egter gebeur sal daar streng gehou moet word by die vereiste van voordeel vir skuldeisers soos in die Insolvensiewet uiteengesit. 


\section{Introduction}

Bread, cash, dosh, loot, moollah, readies, the wherewithal: call it what you like, money matters. ${ }^{1}$

In today's consumer-oriented society this quotation is more relevant than ever. Without money it is impossible to survive. But what is to be done when an individual, for whatever reason, runs out of money? Particularly in South Africa, the majority of persons rely to some extent on the borrowing of money from creditors for their daily and future survival. ${ }^{2}$ But is this a negative trend? Coetzee answers this question in her citation of the INSOL Consumer Debt Report as follows:

"Consumer debts however are no problem per se: they are one of the great dynamic factors in our economies. A high level of domestic consumption is required for both stability and growth. This is why consumers are encouraged by governments to consume. One of the ways to boost this consumption is to facilitate and expand credit facilities for consumers. Consumer debts become a problem when debtors are unable to find solutions for repayment without professional help and that is why society as a whole bears a collective responsibility." 3

This being so, it is also true that historically there has been a need for debtors and creditors to seek professional help when the money runs out and the repayment of debts becomes impossible. ${ }^{4}$ Professional help usually is achieved through legislation, which may vary in form, depending on the type of debtor or the country where the parties are living. 5

In South Africa the three important legislative methods by which debt collection amongst natural persons may be achieved are administration orders provided for by section 74 of the Magistrates' Courts Act ${ }^{6}$; debt review under section 86 of the National Credit Act; ${ }^{7}$ and the sequestration of a debtor's estate under the Insolvency Act. ${ }^{8}$ Only the

1 Ferguson (2008) Ascent of Money 1.

2 For statistics see the Credit Bureau Monitor and Consumer Credit Market Report at www.ncr.org.za (accessed 2018-12-31).

3 See INSOL Consumer Debt Report II 4, quoted by Coetzee 2015 LLD Thesis 1 . For this quotation Coetzee cites the following authors and information: Ramsay 2006 U Ill L Rev 244-245 (the year 2006 for the latter University of Illinois Law Review article should be 2007\} and the Cork Report par 9.

$4 \quad$ See eg Hunter Introduction 122; Wessels History 663; Burdick Principles 271; and Bertelsmann et al Mars 6 for a few sources on the history of insolvency law.

5 See Ferriel and Janger Understanding Bankruptcy par 1.02 for modern theories in bankruptcy law.

632 of 1944 (individual debt collection procedure).

734 of 2005 (hereafter the NCA) (individual debt collection procedure).

824 of 1936 (hereafter the Act or the Insolvency Act) (collective debt collection procedure, as opposed to the individual collection procedure). Only High Courts have jurisdiction over sequestration applications since the individual's status is affected - see ss 2 and 149 of the Insolvency Act 24 of 1936. 
latter procedure affords the parties a method of liquidation of assets culminating in rehabilitation ${ }^{9}$ and a debt discharge or "fresh start" financially. Only this debt collection procedure is considered in this article.

South African insolvency law aims to provide for an equitable distribution of the debtor's property to the advantage of his creditors. It is not expected to benefit the debtor. ${ }^{10}$ The South African Insolvency Act provides for both the voluntary surrender of a debtor's estate and the compulsory sequestration of a debtor's estate. ${ }^{11}$ However, if it cannot be shown that the sequestration will be to the advantage of creditors, a court is unlikely to grant the sequestration order. ${ }^{12}$ But this leads to the possibility that many debtors are excluded from the sequestration route if they do not possess the required assets to show advantage for creditors, thereby also excluding the possibility of a fresh start via rehabilitation. ${ }^{13}$ This has also resulted in the so-called "friendly sequestrations" in compulsory applications and the use of the voluntary surrender procedure for dishonest purposes in several different guises. ${ }^{14}$ One of the methods by which it is attempted to obviate this problem of proving advantage to creditors is where the debtor agrees to waive certain "rights" 15 that a debtor is granted by the Insolvency Act. The value of such rights is intended to increase the value of the estate so that the application complies with the advantage requirement. ${ }^{16}$ In Ex parte Anthony ${ }^{17}$ a court ruled that such waiving of rights was acceptable.

9 See s 129 of the Insolvency Act.

10 Section 3(1) of the Act regulates this. See Bertelsmann et al Mars 48. See also Ex parte Pillay 19552 SA 309 (N) 311 where the court ruled that "the procedure of voluntary surrender was primarily designed for the benefit of creditors, not for the relief of harassed debtors" (per Holmes J).

11 See ss 6, 10 and 12 of the Act.

12 See Loubser 1997 SA MerC LJ 326; Roestoff 2002 LLD Thesis; Evans 2003 SA Merc LJ 437; and Mabe and Evans 2014 SA Merc LJ 651.

13 By implication, this also may exclude creditors from access to the sequestration procedure, particularly where there are several creditors with claims against a debtor. It may therefore occur that only the most vigilant creditor has his claim satisfied in the individual debt collection procedure.

14 See, amongst others, Ex parte Application: Shmukler-Tshiko 2012 JDR 1796 (GSJ); Ex parte Arntzen (Nedbank Ltd as Intervening Creditor) 20131 SA 49 (KZP); Plumb on Plumbers $v$ Lauderdale 20131 SA 60 (KZD); and Huntrex 337 (Pty) Ltd t/a Huntrex Debt Collection Services v Vosloo 20141 SA 227 (GNP) (hereafter the Huntrex case).

15 Hereafter referred to only as "rights", and more specifically, those envisaged in section 82(6) of the Act. Section 82(6) provides:

From the sale of the movable property shall be excepted the wearing apparel and bedding of the insolvent and the whole or such part of his household furniture, and tools and other essential means of subsistence as the creditors, or if no creditor has proved a claim against the estate, as the Master may determine and the insolvent shall be allowed to retain, for his own use any property so excepted from the sale.

16 See $\mathrm{s} 6$ of the Insolvency Act.

1720004 SA 116 (C) (hereafter Ex parte Anthony). 
However, in 2013 a contrary judgment was handed down in Ex parte Kroese and Ex parte Hattingh. ${ }^{18}$ Here Landman J ruled that the rights embodied in section 82(6) of the Act could not be waived. ${ }^{19}$ The court's refusal to allow the waiver in question was based, amongst other aspects, on constitutional imperatives. This resulted in Landman J indirectly focussing on the debtor's dilemma in insolvency proceedings, where the debtor is hampered from receiving any form of discharge from debts by the strict creditor-friendly policy of South African insolvency law. This is particularly evident when confronted by debtors who have no income and no assets (so-called NINA debtors). ${ }^{20}$

In the Kroese judgment Landman J concluded as follows:

"The effect is in my view that the advantage to creditors cannot lawfully be increased by the action contemplated by the applicants. It follows that whatever factors may be raised to show that the applicants, because of external circumstances would not [b]e rendered destitute, are irrelevant because the waiver cannot lawfully be made before the application for surrender of the estate has been accepted."21

While I consider the judgment correct, the reasoning behind the judgment is questioned. However, the interesting aspect of the Kroese judgment is that various constitutional rights of the debtors per se were considered. Nonetheless, the question of the constitutionality of the general policy framework of insolvency legislation, particularly the "advantage to creditors" requirement, was not considered. However, there are indications that there is a movement towards a more debtorfriendly insolvency regime in South Africa, usually based on constitutional requirements, thereby making sequestration proceedings more accessible to "poor" debtors. In this article a few of these developments are considered.

\section{Requirement of Advantage for Creditors}

Sections 6, 10 and 12 of the Insolvency Act require sequestration applications to be to the advantage of creditors. In voluntary surrender applications this requirement is stricter than for compulsory applications as the debtor applying for the surrender of his estate must show that it will be to the advantage of creditors. ${ }^{22}$ For compulsory sequestration applications it only has to be shown that there is reason to

18 Reported as Ex parte Kroese 20151 SA 405 (NWM). See Ndou April 2014 De Rebus 45.

19 The debtors relied heavily on Ex parte Anthony.

20 See generally Coetzee 2015 LLD Thesis.

21 At par 65.

22 S 6(1) of the Act. 
believe that it will be to the advantage of creditors. ${ }^{23}$ This differentiation in proving advantage to creditors results in "poorer" debtors being locked out of the insolvency proceedings.

Coetzee points out that the only solution for such debtors to escape what to the author of this article looks like debt slavery, is to enter into debt rearrangements through voluntary agreement with creditors. Coetzee, however, correctly points out that these debtors are at a disadvantage in negotiations as they cannot offer any monetary return to creditors. 24

The advantage of sequestration proceedings, as opposed to other forms of debt relief, is that they eventually provide the insolvent debtor with a fresh start in his financial position after rehabilitation. But as already mentioned, the advantage to creditors-requirement has resulted in an abuse of sequestration proceedings in both voluntary and compulsory sequestration proceedings. ${ }^{25}$ The courts have been trying to put an end to this abuse. But in doing so no concern has been given to the position of the debtors, particularly NINA debtors, because the South African insolvency regime is creditor-friendly, and:

"[u]nless and until the Insolvency Act is amended, the South African insolvency law requires an advantage to creditors before the estate of an individual can be sequestrated. Much as the troubled economic times might engender sympathy for debtors whose financial burden has become too much to bear, the insolvency law seeks to protect the interests of creditors at least to the extent that a minimum advantage must be ensured for the concurrent creditor when the hand of the law is laid on the insolvent estate." 26

However, this dilemma of certain debtors being denied access to sequestration proceedings has prompted the question whether the foundation of the entire South African insolvency regime, resting on the "advantage" requirement, may be unconstitutional. Concerning this question Coetzee says the following:

"Evans first raised the issue of the possible unconstitutionality of the demonstrated differentiation that occurs in South African natural person insolvency law in the following terms: 'Although the [Insolvency] Act does not provide for different classes of debtors who are to be treated differently in accordance with differing or changing circumstances, it does in fact differentiate between those 'rich debtors' who are able to prove advantage to

23 Ss 10 and 12 of the Act. See Meskin \& Co v Friedman 19482 SA 555 (W) 559. In relation to a practice rule in the North Gauteng High Court, Pretoria, Ex parte Ogunlaja [2011] JOL 27029 (GNP) para 9 (hereafter the Ogunlaja case) found that at least 20 cents in the rand was required to show advantage for creditors. See generally Roestoff 2002 LLD Thesis 347 and further, and Swart 1990 LLD Thesis 273 and further for a comprehensive discussion hereof.

24 Coetzee 2015 LLD Thesis. For an extreme example, see the Huntrex case.

25 See, eg, Smith 1981 MB 59; Smith 1997 JBL 50; and Evans 2001 SA Merc LJ 490 and further.

26 Per Bertelsmann J in the Ogunlaja case par 36. 
creditors, and the 'poor debtors' who cannot. This raises the question whether, under present legislation, the door has been opened for these 'poor debtors' to question the constitutionality of their position." 27

In an informative analysis, Coetzee states that the right to equality, entrenched in both the Constitution ${ }^{28}$ and the Promotion of Equality and Prevention of Unfair Discrimination Act, ${ }^{29}$ must be considered when questioning the constitutionality of the South African insolvency regime. ${ }^{30}$

She states that the equality concept is a difficult and controversial social ideal. She refers to Currie and De Waal who find the challenge of the idea of equality first in determining the similarities in persons' situations and secondly, determining what constitutes equal treatment of those similarly situated. ${ }^{31}$

She submits that all insolvent natural persons are presented with the same problem, being unable to pay their debts and the socio-economic consequences thereof. But what she finds dissimilar is the ability of these different individuals, in different circumstances, to repay their debts. She consequently questions the concept of equality amongst debtors within the context of insolvency law. ${ }^{32}$

In Harksen $v$ Lane, ${ }^{33}$ decided under the Interim Constitution, ${ }^{34}$ the Constitutional Court followed three steps in scrutinising whether a violation of the right to equality had occurred. When applying these steps to the confined access to South African debt relief measures, Coetzee feels comfortable in submitting that:

"[t]he broader natural person insolvency system at the very least differentiates between categories of people, by amongst others drawing a distinction between those who have something to offer creditors, be it assets or income, and those who do not have something to offer. This is so since the 'haves' are allowed access to the system, through one of the three statutory debt relief measures, but the 'have nots' are excluded from any form of statutory recourse. One could possibly argue that this distinction qualifies as discrimination based on the listed ground of 'social origin' which according to Albertyn et al encompasses 'class' and can be used to address unfair discrimination based on socio-economic status. If the exclusion does resort under this ground, discrimination will be

27 Coetzee 2015 LLD Thesis 11-12; Evans 2002 Int Insolv Rev 34. Here Coetzee also cites Steyn 2004 Int Insolv Rev 11; Boraine and Roestoff 2014 THRHR 374; and Boraine and Evans "The Law of Insolvency and the Bill of Rights" par 4A8.

28 S 9 .

294 of 2000 (hereafter the Promotion of Equality Act).

30 Coetzee 2015 LLD Thesis 12.

31 Coetzee 2015 LLD Thesis 14.

32 Coetzee 2015 LLD Thesis 14

3319981 SA 300 (CC) (hereafter Harksen $v$ Lane)

34 Constitution of the Republic of South Africa 200 of 1993 (hereafter Interim Constitution). 
established and unfairness presumed, which will shift the onus to the respondent." 35

Coetzee however finds it problematic that the term "social origin" has not yet been judicially defined. She therefore takes a more conservative stance by accepting that socio-economic status in the present context (or at all) may not necessarily resort under "social origin". Coetzee takes the matter of "socio-economic status" further" ${ }^{36}$ and states that ultimately the constitutional enquiry must ask whether established unfair discrimination can be justified under the limitations clause. For present purposes it is sufficient to agree with Coetzee's conclusion that the initial constitutional enquiry indicates that:

"[t]he broader insolvency system would fail a constitutional challenge - a serious allegation in need of further analysis." 37

But the point that must be made is that the policy of advantage to creditors upon which the South African insolvency system is based, certainly is open to constitutional scrutiny and may even be found to infringe certain provisions of the Constitution. As will be seen below, much evidence is documented in judgments and academic writing to show that desperate 'poor' creditors attempt to obviate the advantage policy by abusing the court procedures in both voluntary and compulsory sequestration procedures.

\section{Waiving Rights to Property for Advantage to Creditors}

It is generally accepted that a solvent debtor is the owner of his property with which he can deal as he wishes. ${ }^{38}$ Generally such property enjoys constitutional protection. ${ }^{39}$ Upon the sequestration of a debtor's estate, however, the insolvent's property vests in the Master and later in the trustee of the insolvent estate. ${ }^{40}$ This property passes to the trustee in

35 Coetzee 2015 LLD Thesis 16. In footnotes 99 and 100 Coetzee LLD Thesis 16 provides the following:

The term "differentiation" is used when a distinction is made on an unlisted ground. See Pretoria City Council v Walker 1998 (2) SA 363 (CC) 380 and Harksen $v$ Lane 321. See also Kok 2011 THRHR 242-244. [It appears that the latter should refer to pages 340-346]. Albertyn et al Introduction 79-80. They argue that the ground refers to one's social group or social status. Class, family and clan membership can all be subsumed under the meaning of social origin. To the extent that social origin can be equated with class, this ground could be used to address unfair discrimination arising from one's low socio-economic status.

See the developments in the judgment of Sarrahwitz v Maritz 20154 SA 491 (CC), discussed below.

36 See Coetzee 2015 LLD Thesis 17.

37 Idem, 19.

38 Badenhorst, Pienaar and Mostert Silberberg and Schoeman's The Law of Property par 1.2.2 on 3 to 4, cited in Ex parte Kroese par 61.

39 See generally s 25 of the Constitution.

40 Ss 20(1)(a) and 2(b) of the Insolvency Act. 
ownership, vesting the dominium thereof in the trustee. ${ }^{41}$ But some property may be excluded or exempted from an insolvent estate. ${ }^{42}$ The common law, court decisions and legislation provide for certain property to be excluded or exempted from the insolvent estate. ${ }^{43}$ Whether assets are excluded or exempted should ultimately determine whether an insolvent debtor may waive his rights to property. It would also determine the value of the estate, and consequently whether there is advantage to creditors. Essentially, the question whether property is exempted from an insolvent estate will arise only after the sequestration order has been granted. This is because in the author's opinion excluded property $^{44}$ never forms part of an insolvent estate. Exempted property does form part thereof but, depending on circumstances, may be exempted from the estate. Property of the estate is exempted by the Master or the creditors in accordance with legislative provisions such as section 82(6) of the Act. The insolvent debtor has no rights to the property in question if it has not been exempted. Section 82(6) of the Act is one legislative provision that provides for property that can be exempted from an insolvent estate, but the word "excepted" is used in that provision. But if the property envisaged in that section of the Act is not exempted it will not be property belonging to the insolvent. ${ }^{45}$ Here the question has arisen whether a debtor may waive certain rights envisaged in the Insolvency Act in order to inflate his estate so as to comply with the requirement of advantage to creditors. Two fairly prominent judgments considered this issue.

\subsection{Court Judgments}

\subsubsection{Ex parte Anthony 46}

This was a full-bench decision in which the waiver of rights envisaged in section 82(6) was not the main issue before the court. But the court found that an insolvent debtor was entitled to waive the benefits embodied in section 82(6). ${ }^{47}$ This judgment was considered correct by Meskin. ${ }^{48}$

41 See De Villiers $v$ Delta Cables (Pty) Ltd 19921 SA 9 (A) 15 I-J. This ruling was accepted in Harksen $v$ Lane par 31.

42 For a comprehensive discussion of excluded or exempted property, see Evans 2008 LLD Thesis Ch 9.

43 Ss 23, 79 and 82(6) of the Insolvency Act regulate excluded and exempted property. Other legislative provisions in this sphere are considered in Evans 2011 PER 38. See Wessels v De Jager 20004 SA 924 (SCA) for an example of court judgments relating to excluded or exempted property.

44 See s 23 of the Insolvency Act for examples of excluded property.

45 Unlike for example the debtor's salary or remuneration, which may be considered "excluded" property, depending of the circumstances; see generally s 23 of the Act.

4620004 SA $116(C)$.

47 At paa 20. It cited SA Eagle Insurance Co Ltd v Bavuma 19853 SA 42 (A) $49 \mathrm{G}-\mathrm{I}$ as authority.

48 Kunst et al Meskin para 3.2. 


\subsubsection{Ex parte Kroese}

This judgment involved two applications for the voluntary surrender of debtors' estates. The applicant debtors attempted to waive the rights referred to in section 82(6) of the Act in order to increase the value of realisable assets in an effort to prove advantage of creditors. In a lengthy judgment Landman J entered into the realms of various constitutional issues relating to the relevant debtors and the property concerned.

The applicants attempted to waive the relevant rights in the following terms:

"I am aware that some of the items listed in the movable property valuation may be viewed as part of basic household necessities, however in terms of section 82(6) of the Insolvency Act 24 of 1936 ('Insolvency Act') I surrender all assets listed in the hands of the Trustee to be appointed herein, thereby waiving the protection afforded by the Insolvency Act pertaining to these assets." 49

\subsubsection{Constitutional issues in Ex parte Kroese}

The court in Ex parte Kroese scrutinised constitutional aspects arising from the waiver of the rights in question. Landman J considered sections 10 and 25 of the Constitution of the Republic of South Africa, $1996^{50}$ dealing with the rights to dignity and property, respectively. He found that one's dignity could be infringed by the renunciation of any benefits found in the Act. Nevertheless, he stated that dignity should not be seen as an absolute right deserving protection under all circumstances. ${ }^{51}$

Landman J questioned whether section 82(6) is constitutionally valid in view of its discretionary nature. ${ }^{52}$ Potentially it could leave the insolvent and his family destitute, depriving them of basic necessities. He thought that here section 25(1) of the Constitution may come into play. ${ }^{53}$ He stated that the discretion to except property, or the refusal to do so, must be exercised reasonably by the Master or creditors, failing which a High Court may intervene. ${ }^{54}$ He found that Ex parte Anthony ${ }^{55}$ was not concerned with waiver of a right to basic necessities, but in any event a waiver:

49 Par 9. By attempting to waive the "rights" to the property envisaged in s $82(6)$ the debtors hoped that the value of the assets concerned would inflate their estates and so show advantage to creditors.

50 Hereafter the Constitution.

51 Par 18.

52 Par 33.

53 It provides: “(1) No one may be deprived of property except in terms of law of general application, and no law may permit arbitrary deprivation of property."

54 Par 34

55 See $n 47$ above. 
"[w]as subject to certain exceptions, namely that no one could renounce a right contrary to law, or a right introduced not only for his own benefit but in the interests of the public as well.,"56

Ex parte Anthony, Landman J ruled, gave inadequate consideration to the restriction on waiver regarding public interest. ${ }^{57}$ Landman J said that the Constitution had to be considered in a reading of section 82(6), also concerning the dignity of persons. ${ }^{58}$ He held that the law is concerned with the dignity of debtors, ${ }^{59}$ referring also to section 67 of the Magistrates' Courts Act ${ }^{60}$ and section 39 of the Supreme Court Act ${ }^{61}$ which provide for protection similar to that found in section 82(6) of the Insolvency Act, but applied in the pre-sequestration debt collection procedure. Landman J further held that section 82(6) partly intended to maintain the right to life and the dignity of an insolvent and his family so that they could start afresh financially. ${ }^{62}$ Landman J also coupled this to section 10 of the Constitution, noting ${ }^{63}$ that all the protections discussed so far are intended to respect the right to life and dignity of persons.

The court found that section 22 of the Constitution concerning the right to work is also linked to the issues at hand ${ }^{64}$ as work supports the notion of self-esteem or dignity. ${ }^{65}$ Landman $\mathrm{J}$ found ${ }^{66}$ that the right to dignity is an inalienable human right. ${ }^{67} \mathrm{He}$ found that the applicants failed to recognise the protective nature of the legislation under consideration. Under the Constitution, based on human rights, it protects debtors and society in general. The state's interest would not be served

\footnotetext{
56 Par 37.

57 Par 38.

58 Par 38. The relevant part of s 1 of the Constitution referred to by Landman J states as follows:

The Republic of South Africa is one, sovereign, democratic state founded on the following values:

(a) Human dignity, the achievement of equality and the advancement of human rights and freedoms.
}

59 Par 39. At par 40 Landman J also referred to Mokgoro $\mathrm{J}$ in Jaftha $v$ Schoeman; Van Rooyen v Stoltz 2005 (2) SA 140 (CC) where she said at 151, with reference to the Magistrates' Courts Act 32 of 1944, that:

"Section 67 of the Act serves to limit the range of movables that may be attached. The section lists certain movables that are exempt from execution in all cases. It is clear from the list that the Act seems to insulate from execution, certain items necessary for the debtor to survive."

6032 of 1944.

6159 of 1959

62 Par 41

63 Par 45. S 10 provides: "Everyone has inherent dignity and the right to have their dignity respected and protected."

64 Par 46.

65 S 22 of the Bill of Rights provides:

Every citizen has the right to choose their trade, occupation or profession freely. The practice of a trade, occupation or profession may be regulated by law.

66 Par 49.

67 As authority he quoted Chaskalson P in $S v$ Makwanyane 19953 SA 391 (CC) par 144. 
if citizens renounced their assets (to create an advantage to creditors) just to become a burden on society. ${ }^{68}$

Whether or not the parties would be destitute if they waived their rights, the court ruled, was irrelevant. This was because the relevant rights could not be waived prior to the sequestration application. ${ }^{69}$ It is submitted that the ruling is correct. However, it is this author's opinion that the analysis of the constitutional issues in this judgment was probably unnecessary. But be that as it may, the court apparently considered the plight of the "poor" debtor important enough to consider his constitutional rights in the light of the stringent policy of advantage for creditors in South African insolvency law. The concern is that some individuals attempt to waive these rights because of the advantage requirement excluding them from applying insolvency legislation, while others are not excluded.

\section{Comment}

\subsection{Advantage for Creditors - Possible Policy Changes?}

Coetzee provides convincing arguments for the point that the advantage for creditors-requirement has the effect of excluding specifically those with no income and no assets from effective debt relief. ${ }^{70}$ This requirement effectively excludes these debtors from the eventual advantage of achieving a fresh start after their rehabilitation. Consequently the very same requirement of advantage to creditors also results in an abuse of sequestration proceedings, both by creditors and debtors. ${ }^{71}$ But as shown above, there are clear reasons for this consequential abuse, and this in turn leads one to question the constitutionality of the foundations of the insolvency system.

As mentioned, Coetzee has considered this problem within the context of the right to equality, entrenched in both the Constitution and the Promotion of Equality Act. As pointed out above, Coetzee finds it problematic that the term "social origin" has not yet been judicially defined, but she is of the opinion that the South African insolvency system may fail a constitutional challenge. ${ }^{72}$ However, the matter of social origin can be taken further by analysing the Constitutional Court ruling in Sarrahwitz $\mathcal{v}$ Maritz $^{73}$ relating to a person's access to housing when insolvency intervenes. Although Sarrahwitz is not directly concerned with waiving of rights and advantage to creditors, the

68 Par 56.

69 Par 65.

70 See par 2 above.

71 See for example Smith 1981 MB 59; Smith 1997 JBL 50; and Evans 2001 SA Merc LJ 490.

72 See par 2 above.

7320154 SA 491 (CC) (hereafter Sarrahwitz). 
arguments there concerning differentiation between persons when insolvency affects a contract, are relevant to this article.

\section{Access to Housing, and Homelessness and Vulnerability}

To build further on Coetzee's arguments it is appropriate to briefly consider the Constitutional Court's judgment in Sarrahwitz. This case concerned the transfer of immovable property to a purchaser thereof after the sequestration of the seller's estate. The approach taken by the Constitutional Court in that judgment related, amongst others, to vulnerable persons and their respective rights. It is discussed here in order to show the similar relationship between a vulnerable purchaser of immovable property (within the sphere of insolvency law), and vulnerable debtors in applications for sequestration of their estates.

Mr Posthumus sold a house to Ms Sarrahwitz in 2002 for R40 000 in a cash sale. ${ }^{74}$ She took occupation in October of that year. Mr Posthumus agreed to arrange for the transfer of the house into her name, which he failed to do. Ms Sarrahwitz made great efforts to achieve the transfer of the property into her name, but in April 2006 when Posthumus's estate was sequestrated, the house had not yet been transferred to Ms Sarrahwitz. The trustee of his insolvent estate (first respondent) refused to transfer the house to Ms Sarrahwitz since the common law dictated that the immovable property fell into the insolvent estate. ${ }^{75}$

To understand the common-law position and the intricacies of this judgment, a summary of the legal development is required. Before 1971 the common law of insolvency dictated that purchasers were prohibited from insisting on transfer of immovable property if the seller's estate had been sequestrated. Purchasers who had paid within a year (and not acquired transfer) and those paying the purchase price in instalments over a period of one year or longer were all affected by this common law rule. Consequently vulnerable purchasers of residential property were deprived of home ownership and the finances already paid to acquire that property. The Sale of Land on Instalments $\mathrm{Act}^{76}$ attempted to remedy this problem by providing for instalment purchasers to have the property transferred to them if the seller became insolvent.

Then the Alienation of Land Act $^{77}$ was enacted to further facilitate transfer of residential property from an insolvent seller's estate to a

74 She had borrowed R40 000 from her employer.

75 Ms Sarrahwitz approached the High Court for an order for transfer but her application was refused on the ground that the common law and not the Act regulated the transfer of the house and that the common law supported the trustee's position. Her subsequent approaches to the Full Bench of the High Court and to the Supreme Court of Appeal failed for the same reason.

7672 of 1971

7768 of 1981 (hereafter the Land Act). 
vulnerable instalment purchaser, the emphasis being on sections 21 and 22 thereof. This statute allows a buyer of residential property, paid for in two or more instalments over a period of one year or longer to obtain transfer if the seller's estate is sequestrated. For the purpose of this article this legislation will not be discussed in further detail.

Ms Sarrahwitz, however, was deprived of the protection of the Land Act because she was a cash buyer.

A majority judgment per Mogoeng CJ was delivered in the Constitutional Court, and Cameron $\mathrm{J}$ and Froneman $\mathrm{J}$ delivered $\mathrm{a}$ concurring minority judgment. This case contained no exceptional circumstances required for the development of the common law, so the court followed a path of a proper interpretation of sections 21 and 22 of the Land Act, premised on the constitutional rights to housing, dignity, and equality.

The Constitutional Court pointed out that poor South Africans in particular may not have access to home loans and are therefore often forced to rely on credit. ${ }^{78}$ Mogoeng CJ said that vulnerable purchasers were at issue, exposing them to possible loss of their residential properties. So the core of this matter concerned homelessness and vulnerability. ${ }^{79}$ Access to adequate housing, the right to dignity, and the right to equality insofar as it relates to the differential treatment of vulnerable purchasers of residential property were relevant in this judgment. ${ }^{80}$ Differentiation is apparent because the legislation excludes vulnerable purchasers, like Ms Sarrahwitz, who paid the full purchase price, but protects equally vulnerable purchasers who paid at least two instalments over a period of at least a year, notwithstanding the seller's insolvency. ${ }^{81}$

Ms Sarrahwitz's application for leave to appeal to the Constitutional Court centred on the argument that the common law is constitutionally invalid because it excludes a person like her from the category of vulnerable purchasers of residential property who are entitled to transfer, in spite of the seller's intervening insolvency. It was also argued that this differentiation denied her equal protection and benefit of the law and was inconsistent with the right to equality, unjustifiable, and therefore constitutionally invalid.

Mogoeng $\mathrm{CJ}$ pointed out that it could never have been the purpose of the Land Act to protect all instalment purchasers, regardless of the means at their command. The purpose could only have been to protect those who need protection, being vulnerable people who would lose their home if the seller's estate was sequestrated. ${ }^{82}$ 
Glen Anil Finance (Pty) Ltd v Joint Liquidators, Glen Anil Development Corporation Ltd (in Liquidation) ${ }^{83}$ was referred to by the court ${ }^{84}$ to explain the reasoning on which the Land Act hinges; and the court considered the judgment ${ }^{85}$ in Merry Hill (Pty) Ltd $v$ Engelbrecht ${ }^{86}$ which made the point that this type of legislation generally protects the vulnerable, uninformed small buyer of residential property who cannot stand up to the large developer in a bargaining situation. ${ }^{87}$

At this point this author submits that the 'poor' debtor in sequestration proceedings may be compared with the various courts' reference to the vulnerable and uninformed. Even worse, it should be noted that in insolvency applications there is no protective legislation for the 'poor' debtors who attempt to enter the sequestration procedure for the purpose of gaining a fresh financial start.

In its judgment the court in Sarrahwitz also said that section 26 of the Constitution was intended to put a permanent end to indignity of this kind. ${ }^{88}$ The court also referred to Jaftha $v$ Schoeman; Van Rooyen $v$ Stoltz ${ }^{89}$ as both cases concerned the right of access to adequate housing, ${ }^{90}$ a socio-economic right, which inevitably implicates the right to dignity. ${ }^{91}$ Mogoeng CJ, however, found that the right to equal protection and benefit of the law was also at issue. ${ }^{92}$ He held that the right to equality is central to the question whether it is constitutionally permissible for legislation to benefit certain vulnerable instalment purchasers to the exclusion of equally vulnerable purchasers who make a one-off payment or pay within one year. ${ }^{93}$

This author again questions whether the vulnerable purchasers in the above judgment are not very similar to vulnerable debtors ${ }^{94}$ in sequestration applications.

The court in Sarrahwitz ruled that section 9(1) guarantees everyone the right to equal protection and benefit of the law. It means that purchasers who are equally vulnerable must enjoy the same protection, irrespective of their method of payment. So the protection conferred by the Land Act upon vulnerable home purchasers must be extended to all other vulnerable purchasers unless the differentiation was justifiable. ${ }^{95}$

8319811 SA 171 (A) 182D-H.

84 At par 36.

85 At par 37.

8620082 SA 544 (SCA).

87 Par 39.

88 Par 41.

8920052 SA 140 (CC).

90 Par 42.

91 Par 43

92 Par 46.

93 Par 47.

94 Strictly speaking also vulnerable creditors in compulsory sequestration applications where advantage to creditors is difficult to prove, or where they attempt to persuade their debtor to waive rights to certain assets.

95 Par 49. 
But the Land Act effectively excludes buyers who pay for the property in full at once or within a period less than one year. This results in differentiation. Harksen $v$ Lane ${ }^{96}$ was referred to in ascertaining whether this differentiation was permissible.

The court consequently had to decide whether that differentiation had a rational connection to a legitimate governmental purpose and whether it was justifiable. The limitation analysis in relation to the impairment of Ms Sarrahwitz's right of access to adequate housing, her right to dignity, and her exclusion from the protection and benefit the Land Act offers to vulnerable instalment purchasers thus had to be considered. ${ }^{97}$ After analysing several Constitutional Court judgments, ${ }^{98}$ the court concluded that Ms Sarrahwitz's situation in essence was the same as that of a vulnerable instalment purchaser whose interests are already protected by the Land Act. No rational basis was found for the protection of one purchaser but not the other. ${ }^{99}$ This legislation was under-inclusive, ${ }^{100}$ violating the right of access to adequate housing and limiting purchasers' rights unjustifiably. ${ }^{101}$

The court found, amongst others, that the impugned provisions to be unconstitutional to the extent that (i) the differentiation they bring about is irrational in that it is not supported by a legitimate government purpose. ${ }^{102} 103$ It is submitted that these questions must also be considered when judging the differentiation between various debtors for proving advantage to creditors in sequestration proceedings.

\subsection{Constitutional Questions}

It must be emphasised here that this article is not a comprehensive analysis of all possible constitutional issues that may relate to the position of different types of debtors (or creditors), advantage for creditors and waiving of rights to property. What is attempted here is an early investigation of these issues, thereby identifying a possible future path that may be trodden. In Ex parte Anthony and Ex parte Kroese the courts should have commenced by questioning whether the rights in question which were sought to be waived were actually in existence prior to or at the time of the sequestration application. Landman J concluded

\footnotetext{
961998 (1) SA 300 (CC) at par 50 of Sarrahwitz.

97 Par 57.

98 See par 58 and further.

99 Par 65.

100 Pars 65-66.

101 Par 66.

102 Par 68

103 Indirectly, however, after the Sarrahwitz house had been excluded by the court as part of Posthumus's insolvent estate, there would probably no longer be any advantage to creditors of Posthumus. By the time of that judgment, however, that issue had apparently become irrelevant.
} 
that they did not exist in his final judgment. It is submitted that his judgment was correct. ${ }^{104}$ However, as previously mentioned, it was probably not necessary to wander into the constitutional implications in the Kroese case. But by doing so, the court indirectly touched on the problems resulting from the strict creditor-friendly policy in South African insolvency law which is inextricably linked to the advantage for creditor requirements. Landman J's judgment seems to indicate the need for a relaxation of this policy.

As a consequence of the discussion above, one can only conclude that within the context of the Kroese judgment concerning waiving of rights to achieve advantage to creditors, there can be no infringement of rights of a constitutional nature. At the relevant moment, prior to sequestration, there simply are no rights of the debtor to be infringed. Whether or not an infringement of the various rights mentioned by Landman J may occur after sequestration if the creditors or the Master refuse to "except" any property in terms of section 82(6), is of course another question.

So, under different circumstances, the constitutional nature of the rights to the property mentioned in section 82(6), and the infringement thereof, could be a consideration. Then, however, one will probably be confronted by facts where the creditors or the Master refuse to "except" the property in question. ${ }^{105}$ The nature of the rights to the property in that section must then be analysed to ascertain what constitutional rights will be infringed. In this respect some of the constitutional rights debated above by Landman J come to mind. It may be argued, as in the Kroese case, that if the insolvent debtor after sequestration is left destitute by the creditors' refusal to "except" certain estate property for his benefit, it may infringe his right to dignity, his right to property, and to practise a trade, occupation or profession freely. However, the dilemma of the "poor" (vulnerable) debtor is that the requirement of advantage to creditors initially excludes him from accessing the legislative sequestration procedures that are available to "wealthy" debtors, and consequently also the advantage of attaining a fresh financial start through rehabilitation. So the vulnerable debtor has no access to the law of insolvency in the first place and cannot even test his constitutional rights to property (or any other rights) that he may be entitled to if he achieved sequestration of his estate. This obstruction will not apply to applicants who can show advantage to creditors and who then gain access to section 82(6) and other advantages of sequestration (such as rehabilitation and absolution from debts) after a sequestration order has been granted.

104 For a comprehensive discussion of this issue, see Evans and Mathethwa 2014 SAPL 548-565.

105 See also ss 23(12) and 79 of the Insolvency Act, which also make provision for a type of subsistence allowance for the insolvent. It is submitted that a refusal by the trustee or Master to allow the insolvent such benefits could also result in an infringement of the constitutional rights under discussion. 
But if compared with the Sarrahwitz judgment, it is possible that similar findings as in the latter case may result if the requirement of advantage to creditors is put through constitutional scrutiny.

But Mogoeng $\mathrm{CJ}$ found that also the right to equal protection and benefit of the law was at issue in the Sarrahwitz judgment. ${ }^{106}$ The court confirmed that section 9(1) of the Constitution guarantees everyone the right to equal protection and benefit of the law. It means that purchasers who are equally vulnerable must enjoy the same protection, irrespective of their method of payment. As will be shown below, it is perhaps precisely on this basis that the advantage to creditors requirement may be attacked. Under the present insolvency dispensation, the more vulnerable the applicant is, the less likely he is able to access the remedial provisions and protection of insolvency legislation. There is no equal protection and benefit of the law. Differentiation between debtors at the point of application for a sequestration order clearly exists between different debtors. Ironically, there is also then a differentiation between creditors who are affected by the inability to share in the proceeds of an insolvent estate when a sequestration order is unobtainable. A concursus creditorum cannot be established, so it is possible that only one creditor, amongst many, may have his claim satisfied in an individual method of debt collection.

In Sarrahwitz the court consequently had to decide whether the differentiation in that judgment had a rational connection to a legitimate governmental purpose and whether it was justifiable. ${ }^{107}$ No rational basis was found for the protection of one purchaser but not the other. ${ }^{108}$

\section{Conclusion}

It is well documented that the requirement of advantage to creditors has led to the abuse of the sequestration procedure in South African law, both by debtors and creditors. The reason why this occurs usually is because applicants who are anxious to surrender their estates, or have their estates sequestrated by creditors, are unable to show advantage to creditors in normal sequestration procedures. They have no way of escaping their indebtedness through access to insolvency legislation.

It is also a fact that South African insolvency law is geared towards the interests of creditors, providing meagre respite for debtors. The introduction of different forms of consumer legislation to improve the position of South African debtors prior to resorting to sequestration ${ }^{109}$

106 Par 46

107 Par 57.

108 Par 65.

$109 \mathrm{Eg}$ the NCA. 
does not appear to have alleviated the practice by anxious debtors to try to have their estates sequestrated, often with impure motives. ${ }^{110}$

By analysing possible constitutional infringements in the Ex parte Kroese judgment, Landman $\mathrm{J}$ indirectly questioned South African insolvency law policy which pays scant attention to the dilemma of certain classes of debtor. It seems correct to say that the Insolvency Act is a law of general application as envisaged by section 36 of the Constitution. Once a sequestration order has been granted, one may, sometimes misleadingly, argue that the rights of several parties in the process appear to be infringed. But the very nature of the insolvency arena is such that insolvency law limits the rights of most of its participants. Most, however, would agree with Jackson who says that it is generally accepted that in principle collectivised debt collection through a bankruptcy procedure is beneficial. ${ }^{11}$ But this is perhaps a valid argument only once the insolvency procedure commences, and the relevant debtors have already passed through the gates of sequestration. If some are prohibited from passing through those gates at all, then questions of constitutional infringement of rights may arise. There appears to be differentiation between parties who can access the mechanisms of insolvency legislation.

Law reform in South African insolvency legislation has been pending for many years. ${ }^{12}$ Several different versions of the Insolvency Bill have been produced. The Law Reform Commission has consistently opined that the requirement of advantage for creditors must form part of future legislation. ${ }^{113}$

The justification for this is that:

"[i]t is unacceptable to use the expensive procedure of liquidation by the court in cases where the value of the assets is insufficient to ensure a benefit to creditors." 114

But if one applies the reasoning of the Constitutional Court in Sarrahwitz to the policy of advantage to creditors, the provisions of the Insolvency Act may be found to be unconstitutional based on precisely the same infringements of vulnerable persons as in Sarrahwitz.

110 See the Huntrex case for a recent example of the extreme abuse of consumer legislation.

111 Jackson (2001) Logic and Limits 7.

112 The South African Law Commission published a report entitled the Report on the Review of the Law of Insolvency in 2000. It contained a draft bill as well as an explanatory memorandum - hence the "2000 Insolvency Bill" and "2000 Explanatory memorandum" respectively. The latest versions of the documents are unofficial working copies on file with the author (hereafter Bill or 2015 Insolvency Bill and 2014 Explanatory Memorandum respectively).

113 See Coetzee fn 35, 36 and 37.

1142014 Explanatory Memorandum para 3.15. 
In this respect Millman comments that if insolvency law is seen as a product that the state offers its citizens, then one must enquire whether:

"[i]t provides the optimum balance between promoting justice between the various stakeholders and achieving the goal of economic efficiency." 115

He correctly states that the chosen insolvency system must consider the changing norms and formative perceptions of society. ${ }^{116}$ This is of particular importance in South Africa where current legislation was introduced nearly a century prior to the current Constitution which ushered in policies based on democratic values and equality.

It is submitted that much of insolvency legislation has as its consequence the "justifiable limitation" of various rights of various classes of persons. Virtually any insolvency regime, by its very nature, infringes the rights of most of the parties concerned, including creditors, debtors, the state and, arguably, society in general. However, these limitations, it is submitted, are in place generally for the benefit of all parties concerned in an open and democratic society based on human dignity, equality and freedom. ${ }^{117}$ It is probably acceptable to note that the Act's provisions are mostly justifiable within the limitation criteria of section 36 of the Constitution, once the insolvency mechanisms have been accessed. But as described above, the exclusion of certain members of society from accessing insolvency proceedings and the consequential fresh financial start they can produce, appears to infringe the rights of particularly vulnerable members of society. Here it is worth repeating Coetzee's opinion that the equality concept is a difficult controversial social ideal. ${ }^{118}$ But if the Sarrahwitz ruling is considered, much of the equality concept, in the context of the present article and advantage to creditors, is dealt with. If the Sarrahwitz judgment has been correctly understood, then one further has to agree with Coetzee when she says that all insolvent natural persons face an equal problem, namely, the inability to pay their debts and the socio-economic consequences hereof. ${ }^{119}$ What she finds dissimilar is the ability of these different individuals, in different circumstances, to repay their debts.

The Sarrahwitz judgment is a complex intellectual cactus, near impossible to grapple with. It affects more than merely the provisions of the Land Act. On the one hand, it looks after the interest of one creditor $^{120}$ only, and this interferes with the concursus creditorum principle. On the other, it indirectly interferes with the common-law principles regarding the transfer of immovable assets that belong to

115 Millman (2005) Personal Insolvency Law 2.

116 Ibid 2.

117 See Currie and De Waal (2013) Bill of Rights Handbook par 7.1.

118 See par 2 above.

119 Ibid.

120 Or party to a contract. 
insolvent estates. It also considers the existence of "vulnerable" persons ${ }^{121}$ without any indication how such qualities or persons must be identified. This has created an even pricklier problem for sequestration applications, since one is essentially dealing with differentiation between three different classes of debtors in the debt collection procedures, ${ }^{122}$ and the possible differentiation between creditors. In this author's opinion, Sarrahwitz has serious implications for the future development of insolvency law in South Africa, leaving more questions than answers. That is a fertile subject for further research. ${ }^{123}$ In the context of the present article, and considering the position of "vulnerable people", it is predicted that the provisions of the Act regarding advantage to creditors that exclude persons from accessing sequestration proceedings may be successfully challenged in the courts, sooner rather than later. But until then:

"[u]nless and until the Insolvency Act is amended, the South African insolvency law requires an advantage to creditors before the estate of an individual can be sequestrated. Much as the troubled economic times might engender sympathy for debtors whose financial burden has become too much to bear, the insolvency law seeks to protect the interests of creditors at least to the extent that a minimum advantage must be ensured for the concurrent creditor when the hand of the law is laid on the insolvent estate." 124

121 It is submitted that these could be either debtors or creditors in the context of Sarrahwitz.

122 Meaning first, debtors in the individual debt collection procedure; secondly, debtors who cannot access the individual procedure or the collective sequestration procedure; and, thirdly, those who can access the insolvency mechanisms in the Insolvency Act.

123 It is the author's opinion that the strict requirement of advantage to creditors is in its very foundation ill conceived. Essentially, it should not have a place in a modern constitutional democracy because it serves merely as a vague measure to give a court the discretion to decide what the future will hold for both debtors and creditors in the debt collection process. It is common knowledge that concurrent creditors rarely receive advantage from the sequestration of individual debtors' estates, and generally prefer not to prove claims for fear of having to make a contribution to the cost of the sequestration of the debtor. The classification and ranking of creditors in itself also qualifies as a form of differentiation (between creditors), but that will be discussed in a future article.

124 Per Bertelsmann J in the Ogunlaja case par 36. 